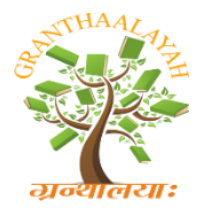

\author{
INTERNATIONAL JOURNAL OF RESEARCH - \\ GRANTHAALAYAH \\ A knowledge Repository
}

Science

\title{
REDESIGN OF WATER RECYCLING SYSTEM IN ASTRA PROPERTY JAKARTA SELATAN AREA WITH OEE METHOD TO INCREASE CLEAN WATER EFFICIENCY IN SERVING INCREASED CONSUMERS
}

\author{
Surasa $^{* 1}$, Revino ${ }^{2}$, Franka Hendra ${ }^{3}$ \\ ${ }^{* 1}$ Industrial Engineering Postgraduate Program, National Institute of Science and Technology, J1 \\ Moh. Khafi II, Bumi Srengseng Indah, Jagakarsa, South Jakarta \\ ${ }^{2}$ National Institute of Science and Technology Lecturer, Jl Moh.Khafi II, Bumi Srengseng Indah, \\ Jagakarsa, South Jakarta \\ ${ }^{3}$ Industrial Engineering, Universitas Pamulang, J1. Surya Kencana, No. 1
}

\begin{abstract}
Water demand is increasing, but thus water resources are increasingly threatened due to the increasing use and pollution of the environment, therefore there is a need for long-term strategies regarding water use in order to maintain the sustainability of water resources in Indonesia, especially in the DKI region

This study shows the effective steps in the efficient use of the water in the Astra South Jakarta property area, by reengineering the water recycling system, which uses the Overall Equipment Effectiveness (OEE) method.

The results of this design have been able to increase engine effectiveness from $51.9 \%$ to $88.9 \%$ and water recycling productivity up $168 \%$ (production from $20 \mathrm{~m} 20$ to $54 \mathrm{~m}^{3}$ per day), so that can reduce PDAM water supply $16.6 \%$ (water requirement before the system re design are an average of 4,088.2 $\mathrm{m}^{3}$ per month, after redesigning the system $3,407 \mathrm{~m}^{3}$ per month). The redesign of the system is also able to prepare water reserves that can supply water for the development of Astra properties in the area of around $20 \mathrm{~m}$ per day. At DKI Profession level, the design of the reengineering can contribute to the DKI Jaya, the water supply of $0.00002 \%$ per day and can reduce the utilization of ground water because the water needs in Astra have been fulfilled.
\end{abstract}

Keywords: Redesign of Water Recycling System Improves Water.

Cite This Article: Surasa, Revino, and Franka Hendra. (2019). "REDESIGN OF WATER RECYCLING SYSTEM IN ASTRA PROPERTY JAKARTA SELATAN AREA WITH OEE METHOD TO INCREASE CLEAN WATER EFFICIENCY IN SERVING INCREASED CONSUMERS." International Journal of Research - Granthaalayah, 7(9), 1-10 https://doi.org/10.29121/granthaalayah.v7.i9.2019.551. 


\section{Introduction}

Water needs are increasingly increasing, but thus water resources are increasingly threatened due to the increasing use and pollution of the environment, therefore the need for long-term strategies on water use in order to maintain the sustainability of water resources in Indonesia, especially in the DKI Jakarta area. starting from the water use management system by processing domestic waste into water recycling in buildings in DKI, whose growth is increasing every year.

Building developments, especially in the DKI Jakarta area, are very rapid, judging from the first founding history of tall buildings in Indonesia starting from buildings in Jakarta, namely the Sarinah building in 1963 which has a height of 74 meters with a total of 15 floors. tall buildings in DKI reached 1,719 buildings consisting of the area of south Jakarta 571, central Jakarta 561, west Jakarta 302 and south Jakarta 141. Indonesian Forum Skyscrapercity Data in 2017 Jakarta has skyanchoring buildings up to number 7 in the world, with 362 buildings after Sanghai 366 building in a very rapid building development shows that the building management service industry is highly developed, therefore the development and optimization of building maintenance systems need to be improved in order to maintain water stability according to the mandate of Law No. 7 of 2004 concerning water resources, government regulation No. 121 In 2015 concerning water supply, the 2013 Republic of Indonesia Minister of Public Works 12 / PRTM / 2013 regulation on saving water use originating from providers of water supply systems. Although water facilities are guaranteed by the government, but to meet the needs of the industry, water needs have to cost not a little, but if the rules for use of ground water are not limited, they will preserve sustainability. environment and forestry that the quality of river water has been contaminated. While the fresh water supply contained in the earth is only $3 \%$ then $97 \%$ is sea water, while for the $2 / 3 \%$ of the fresh water it forms ice cubesahan therefore the need to pay attention to its use so that natural sustainability is guaranteed.

Based on Amrta Institute research, the need for clean water in DKI Jakarta is increasing every year. in 2015, clean water needs reached 1.2 billion cubic meters, an increase of one percent from the previous year. Of this amount, only 36 percent is met by the flow of PDAMs, the rest use ground water, it is estimated that the capital's water needs will increase by 25 thousand liters per second in the following year, to meet daily water needs, millions of people use ground and river water, plus groundwater exploration by buildings in urban areas such as DKI Jakarta which can potentially damage the environment considering excessive water withdrawal causes a decrease in the surface of the land every year, another thing if viewed from the health factor of water feasibility according to the Amrta Institute study, the institution who conducted groundwater and river research in DKI, 93 percent of river water and land in Jakarta were exposed to Escherichia col bacteria, reaching up to 2 million per 100 cubic millimeters of water, even though the tolerance limit of this bacteria was only 2,000 per 100 cubic millimeters, even if viewed from the level the potential for Indonesian water resources to keep up world number five for water resources, even though Indonesia is ranked 5 in the world of its water resources Indonesia will experience a water crisis, especially Jakarta, as predicted by researchers grouped in 10 cities in the world that it is threatened that the water in the table is as follows : 
Table 1: Cities in a World Threatened by Water shortages

\begin{tabular}{|c|c|c|c|}
\hline No & City name & Country & Reason \\
\hline 1 & São Paulo & Brazilia & $\begin{array}{l}\text { Drought which hit in } 2014 \text { and 2017, to only have water } \\
\text { reserves for } 20 \text { days }\end{array}$ \\
\hline 2 & Bangalor & India & $\begin{array}{l}\text { Rapid property growth until rivers and lakes are polluted } \\
\text { which eventually } 85 \% \text { lake water and there is no use as } \\
\text { needed }\end{array}$ \\
\hline 3 & Beijing & Cina & $\begin{array}{l}\text { only has } 7 \text { persediaan of water supply until in } 2014 \text { bejing } \\
\text { only gets } 145 \mathrm{~m}^{3} \text { of water per person per year which should } \\
\text { be } 1000 \mathrm{~m} \text { dunia of world bank data }\end{array}$ \\
\hline 4 & Kairo & Mesir & $\begin{array}{l}\text { Egypt } 97 \text { air water source from the Nill river which at the } \\
\text { moment is polluted by UN waste estimates that in } 2025 \text { the } \\
\text { country will have a water crisis }\end{array}$ \\
\hline 5 & Jakarta & Indonesia & $\begin{array}{l}\text { Exploration of excessive water and water absorption is } \\
\text { limited because the land is covered in concrete and asphalt. }\end{array}$ \\
\hline 6 & Moskow & Rusia & $\begin{array}{l}30-60 \% \text { contaminated groundwater due to the inheritance } \\
\text { of the soviet industry }\end{array}$ \\
\hline 7 & Istambul & Turki & $\begin{array}{l}\text { Water supply dropped to } 1700 \mathrm{~m}^{3} \text { per capita because the } \\
\text { reservoir was dry up to } 30 \%\end{array}$ \\
\hline 8 & Mexico & Amirika & $\begin{array}{l}\text { One in } 5 \text { residents only gets water only a few hours from } \\
\text { the tap because the water supply is lacking and does not } \\
\text { have a large scale to recycle waste, }\end{array}$ \\
\hline 9 & London & Inggris & $\begin{array}{l}\text { wastage in the water hose for public areas up to } 25 \% \\
\text { estimated that in } 2025 \text { there will be a water crisis }\end{array}$ \\
\hline 10 & Tokyo & Jepang & $\begin{array}{l}\text { Sumer water from rain water which is only } 4 \text { months } \\
\text { duration every year if it rains less than four months it is } \\
\text { predicted a water crisis }\end{array}$ \\
\hline
\end{tabular}

(Source: World Research Institute (WRI)

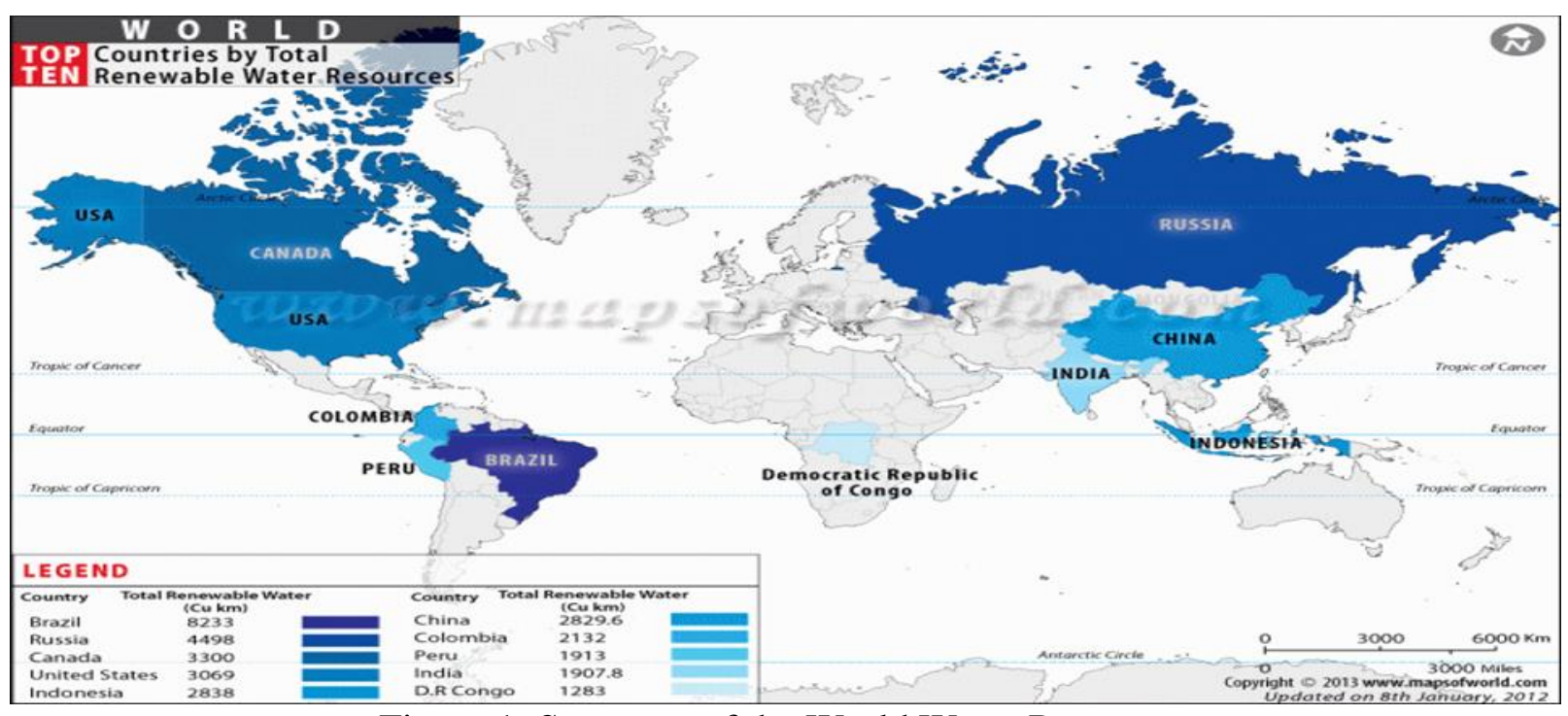

Figure 1: Sequence of the World Water Resources

(Source: DKI Statistics Agency) 
The efforts of the provincial government in collaboration with the water supply company PDAM seeks to meet the needs of the people of the province of DKI by optimizing its production to bring in $97 \%$ of raw water from outside Jakarta, namely from Cisedani River, Jatiluhur Reservoir and also Cikokol River, while 3\% from Jakarta is only in Jakarta. supply from Krukut and Pasanggrahan times, while 15 other rivers cannot be utilized due to pollution. Based on the review of the DKI Jakarta provincial statistical body (BPS) in 2017 the water production capacity in the province compared to the previous year has increased as shown in Figure 2 graphic of clean water production in DKI as follows:

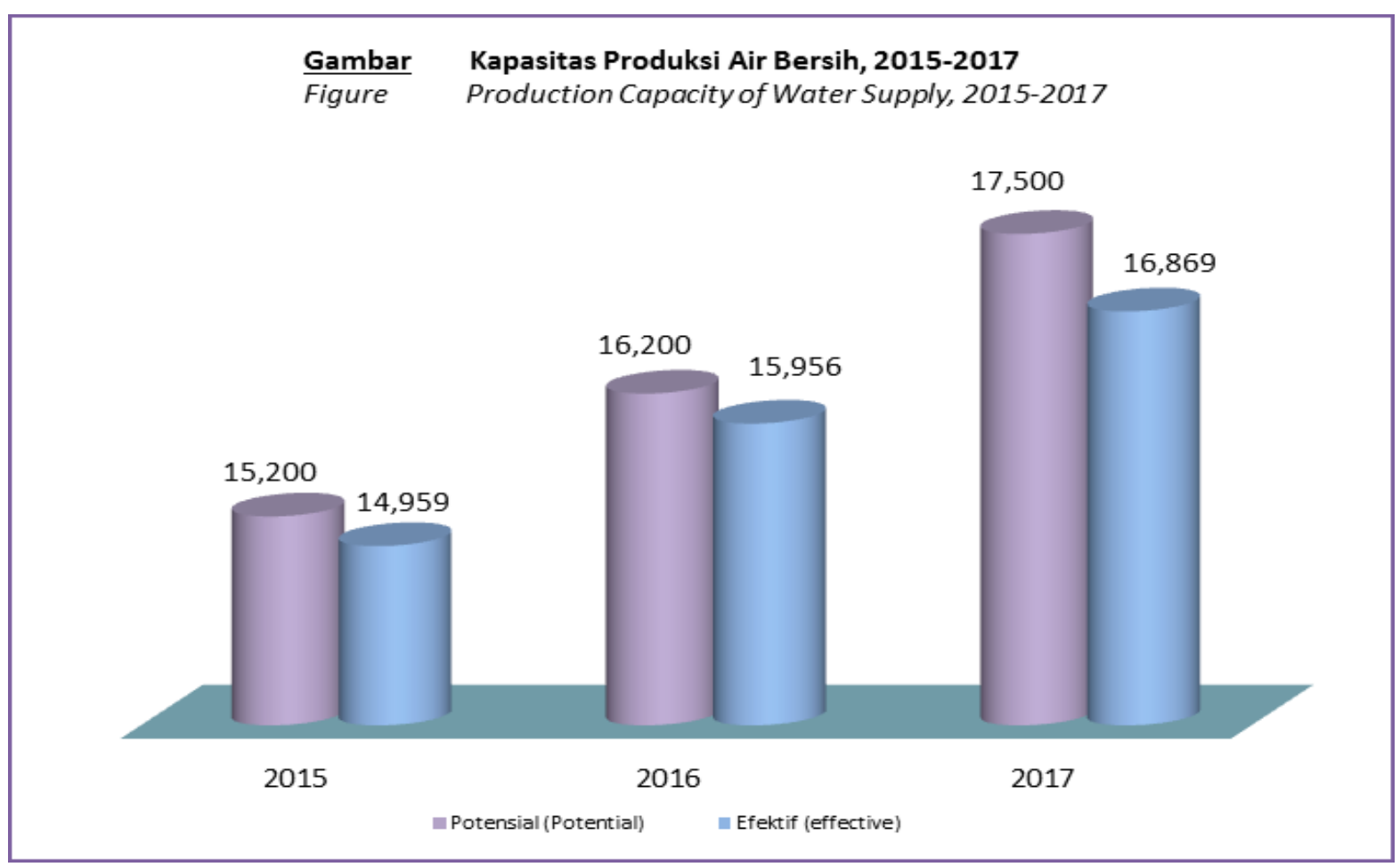

(Source: DKI Statistics Agency)

Figure 2: DKI Clean Water Production Capacity

\section{Methodology}

In this study, researchers analyzed the level of efficiency in the use of water and analyzed the water recycling system at the STP and then explained the causes of the water consumption being inefficient 


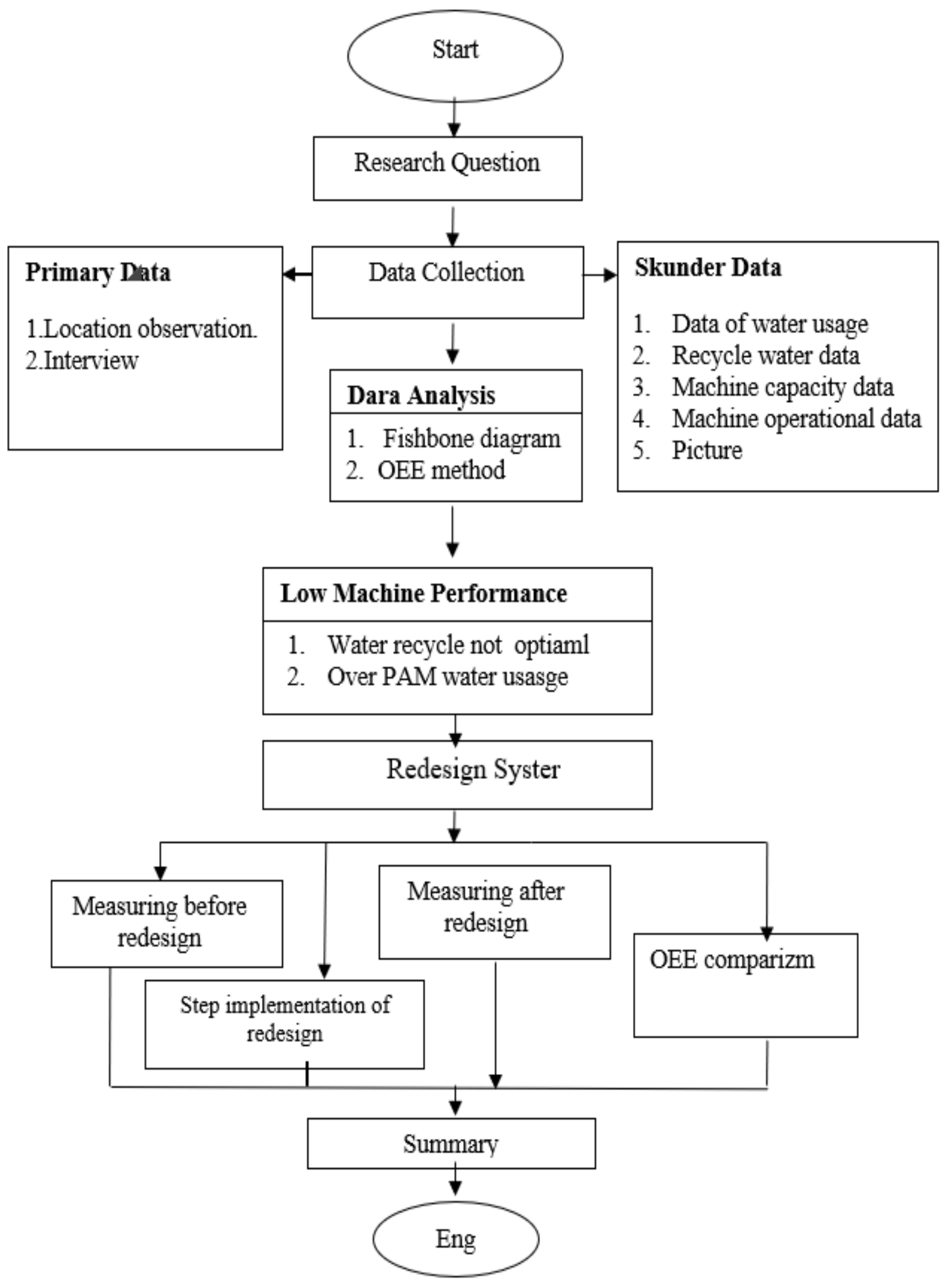

Figure 3: Research Flow 


\section{Result and Discussion}

The data processed in this study were processed using tools that fit the subject of the discussion, Overall Equipment Effectiveness (OEE). The OEE calculation is used to determine the total effectiveness of the machine used in water recycle (water recycle) that comes from domestic waste as a whole.

\subsection{Analysis of Data and Research Results.}

The company in anticipation of the surge in water demand and environmentally friendly strategies required for the Astra Group company through the AGC (Astra green company) concept, has carried out its sewage treatment process with the sewage treatment plan (STP) method, which is a biological system whose processes utilize decomposing bacteria that require oxygen and reprocessing STP out put into water recycle, with a carbon filtering system but even though it has managed waste to be processed as recycled into clean water the use of water from PAM is still lavishly complained, therefore it is necessary to identify the data as follows:

\subsection{PDAM Water Supply Data}

From the data of water consumption for 3 years counted the average water usage per day as in Table 2 are as follows:

Table 2: Average Water Use for 2015 - 2017

\begin{tabular}{|l|l|l|}
\hline Nb & Year & Everage/day $\left.\mathbf{( m}^{\mathbf{3}}\right)$ \\
\hline 1 & 2015 & 143,8 \\
\hline 2 & 2016 & 145,6 \\
\hline 3 & 2017 & 146,8 \\
\hline
\end{tabular}

(Source: Data Processed)

\subsection{Water Recycling Production Data}

Water recycling production as follows:

Table 3: Recycling of Water in 2015-2017
\begin{tabular}{|l|l|l|}
\hline No & Year & Everage/day $\left(\mathbf{m}^{\mathbf{3}}\right)$ \\
\hline 1 & 2015 & 20,3 \\
\hline 2 & 2016 & 20,1 \\
\hline 3 & 2017 & 20,1 \\
\hline
\end{tabular}

(Source: data processing results)

\subsection{Fishbone Diagram Analysis.}

Fishbone diagram for system redesign as follows: 


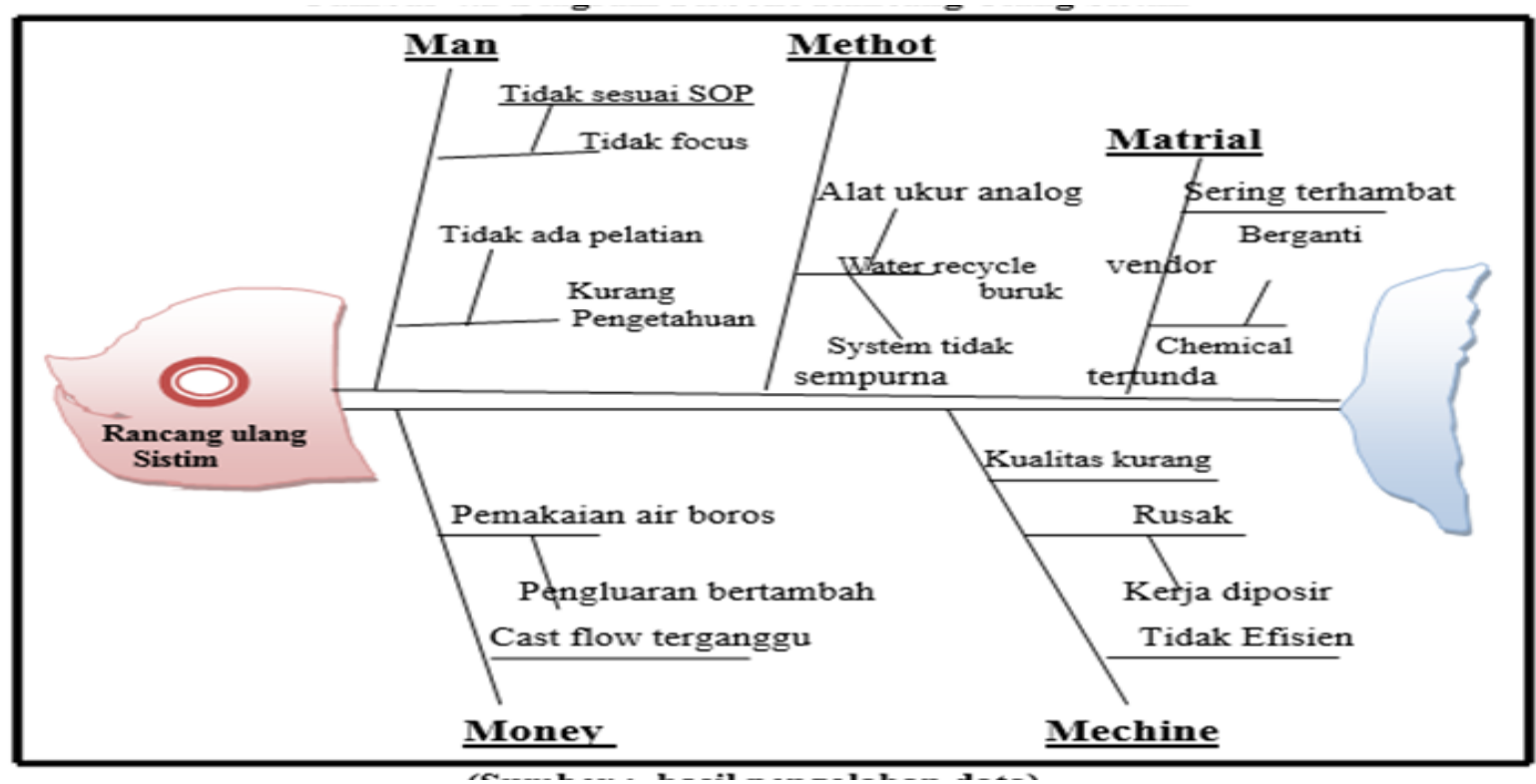

Figure 4: Fishbone diagram

\subsection{Water Recycling Production System Analysis}

The recycled water production in the Astra Property area is felt to be less than optimal and unbalanced when compared to the investment in the equipment used, the alleged inadequate production is in accordance with the results of research and observations in the production system. Many supporting components are found that are not in accordance with the provisions. redesign the system so that production can be optimized.

\section{Discussion}

Based on the analysis using Fishbone diagram, OEE analysis of water consumption data and also direct observations, regarding water recycling which is less effective, steps are taken to repair and change the system with redesign so that recycled production can meet demand can also supply needs to property development required other steps as follows:

1) Change the installation of the blower pipe for air distribution from the blower to the diffuser from PVC pipe material to galpanis. From the results of observations and research air distribution from the machine blower to the diffuser is made of PVC material that does not have enough pans resistance, while the air that is channeled through the pipe comes from engine compression has a high temperature up to $90^{\circ} \mathrm{C}$, the pipe made of PVC material wrinkles to the effect of disturbed air circulation.

2) Change the diffuser from an open system to a closed system. Open diffuser system will be at risk when the air does not flow because active sludge will enter the pipe and seal, it can cause blockage in the flow of the pipe so that bacteria will die and the waste will not be decomposed so the recycle will be disrupted even the waste quality standard will not be reached.

3) Change the design of waste circulation by adding a floating valve to the effluent pump to the supply water recycle tank. 
4) Floating valve is a control level of water in the tank, which works if the water is full it will close the valve automatically with mechanical movement, and if the water is empty the valve will open automatically because the pendulum will hang and move the valve to open automatically.

5) Replacing the check valve in the supply engine blower, two alternating blower units need a good check valve that is useful for anticipating air that leaks into the engine because if the check valve does not work properly there will be air leakage entering the engine that is not operating so the air supply to the defuser is not maximal.

\subsection{Results Obtained After System Redesign}

Improved water recycling treatment system results can be seen in the fall of Water utility bills and water usage due to water usage are subsidized by adequate water recycling as shown in Figures 4 and 5 as follows:

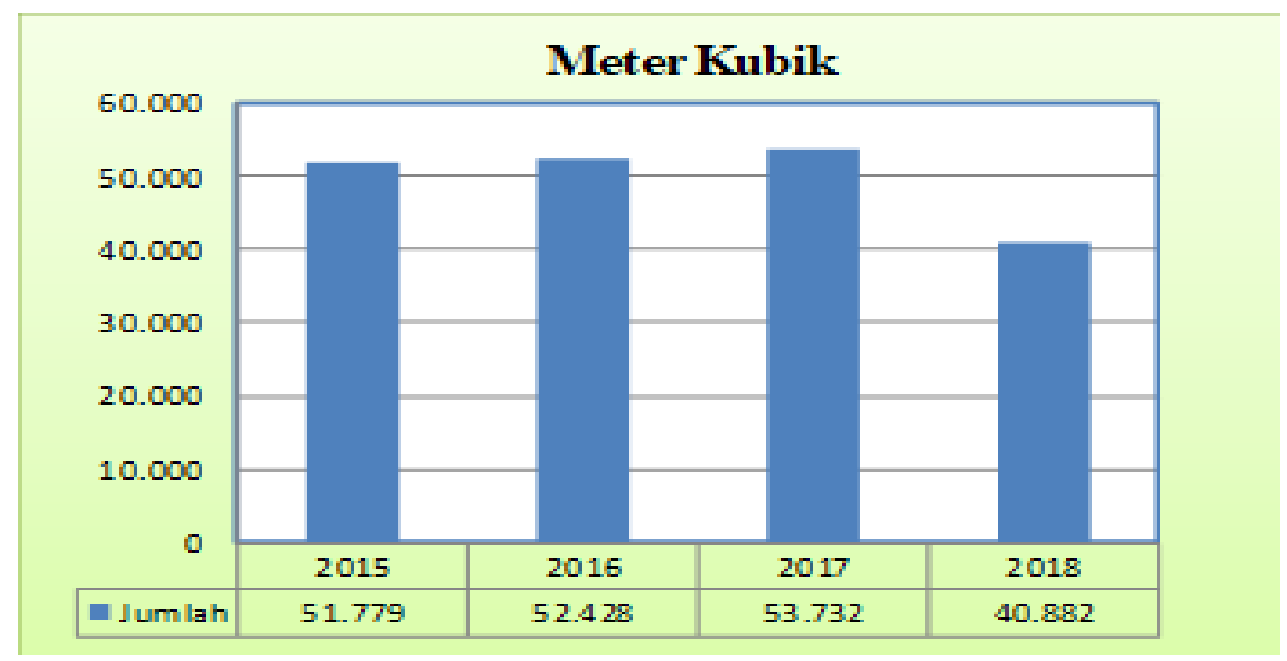

Figure 5: Comparison of post-redesign water consumption

(Source: Data processed)

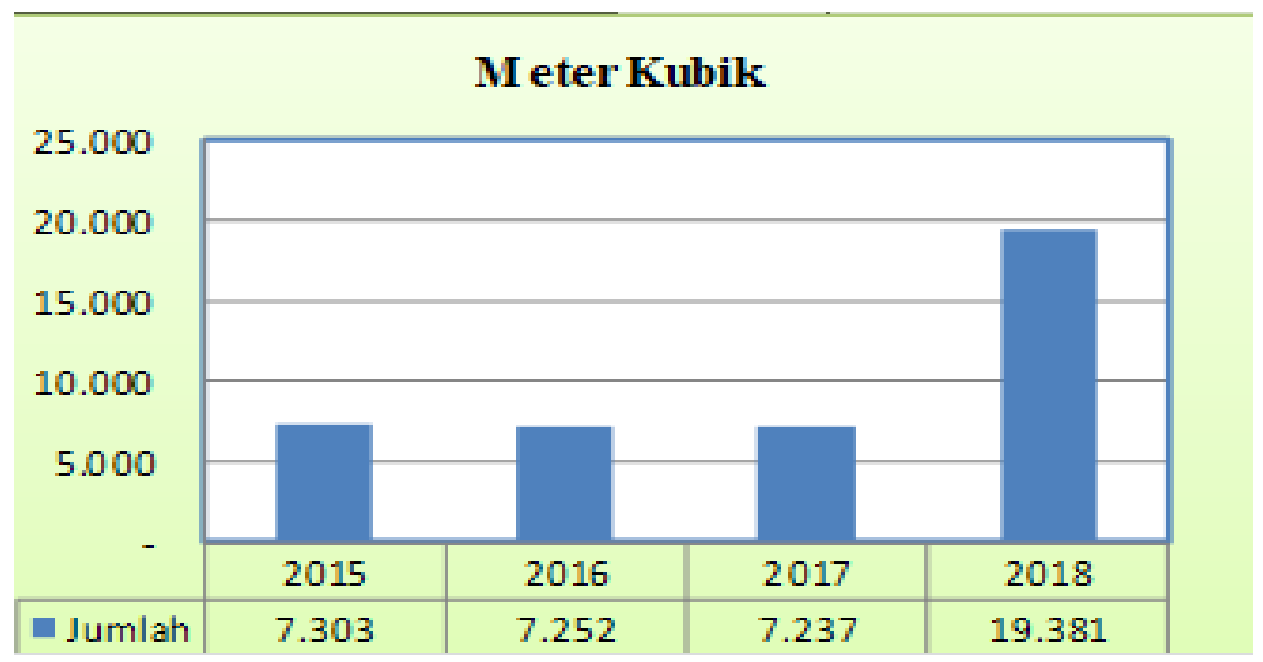

Figure 6: Comparison of post-recycling water production (Source: Data processed) 
Table 3: Comparison of OEE Values after Redesign

\begin{tabular}{|l|l|l|l|l|l|l|}
\hline \multirow{2}{*}{ Nb } & \multirow{2}{*}{ Variable } & \multicolumn{3}{|l|}{ Before redesign } & Average & After Redesign \\
\cline { 3 - 7 } & & 2015 & 2016 & 2017 & & 2018 \\
\hline 1 & Availability & $80,7 \%$ & $79,9 \%$ & $75,8 \%$ & $78,5 \%$ & $94.5 \%$ \\
\hline 2 & Performance & $75 \%$ & $74 \%$ & $74 \%$ & $74,3 \%$ & $97 \%$ \\
\hline 3 & Quality & $89 \%$ & $90 \%$ & $88 \%$ & $89 \%$ & $97 \%$ \\
\hline & & & & & $51,9 \%$ & $88,9 \%$ \\
\hline
\end{tabular}

(Source: Data processed)

\section{Conclusions}

The steps in optimizing the water efficiency system are to analyze and then redesign the machine productivity system and the processing system for recycling wastewater into clean water. The applied system is to improve the production process by changing the installation desing, such as piping from the original using PVC pipes then replaced with galpanis pipes, circulation of water initially with over flow without borders then change with over flow using ploating approach in use the function of the original spere part using a diffuser to supply air from the blower machine with an open system not using a membrane then changing it using a membrane. The efficiency obtained by astra as a consumer after the system redesign is an increase in production per day from the original $20.1 \mathrm{~m}^{3}$ to $54 \mathrm{~m}^{3}$ or an increase of $168 \%$ so that it can increase water savings $33.9 \mathrm{~m}^{3}$ per day or save $\operatorname{Rp} 425,445$, per day and increase business effectiveness overall machine from OEE calculations before $51.9 \%$ to $88.9 \%$ calculations up $71 \%$. If the savings calculated by the total production of clean water in DKI Jaya in 2017 are 16,869 liters per second or 1,457,482 $\mathrm{m}^{3}$ per day, then the redesign of the water recycling system can contribute $0.00002 \%$. of the total clean water production of DKI Jakarta Province.

\section{References}

[1] Alpi Rahmi 2016, Water Treatment Turns into Domestic and Non Consumption Water with a Biosand Filter Activated Carbon, Civil Engineering Laboratory, Pasir Pangaraian University.

[2] Abdul khaliq 2015, Analysis of Waste Management in Klayan Luar Kelurahan IPAL Peka [uran Raya PD PAL Banjar Masin City

[3] Ahmat Ansory 2011, Effectiveness and Efficiency of Irrigation Networks on Water Needs in Kaiti Samo Irrigation Plants in Rambah District, Rokan Hulu Sri Regency

[4] Analysis of the Access of the DKI Jakarta Community to Water Post Water Pripatization in 20092014

[5] Hery Suliantoro 2017, Application of Overall Equipment Effectivenees (OEE) Method and full try Analysis to Measure Leng Machine Effectiveness, Diponegoro University Semarang.

[6] Harista Gustinata Wati 2017, Optimization of Water Treatment in Muara Jambi.

[7] Helina Lenih \& conception rey Majis (2009). "Charges in the Industrial Water Sector" Journal of Econ Environmental Resources.

[8] Asuhiro Inatshu, Chiraorna Ananchaipattana, Low Cost Suitanable Technology for the production of clean drinking water, Jrnal of antivirroment protection, Shubaki Japan 4 Department of biology 2014.

[9] Nusa Idaman Said 2006, Recycling of Waste Water (water Recycle System) reviewed from Asfek Technology, Environment and Economics, Center for Environmental Technology Agency for Application of Technology (BPPT). 
[10] Ross Kenneth Kennedy, Understanding, Measuring, and Improving Overall Equipment Effectiveness.

[11] Sri Subekti 2005 Hospital Clean Water Treatment as an Effort to Minimize Liquid Waste, Ungaran General Hospital.

[12] Sanfra Madona 2014, Energy Efficiency through Water Savings, Case Study of the Institute of Higher Education at Bakrie University.

[13] DKI Jakarta Clean Water Statistics 2015 - 2018.

[14] Wahyu Hidayat 2017. Optimization of the Ovral Performance of the Water Purification System, in the Tawang Industrial Park Industry Area.

[15] Regulation of the Minister of Health Number: 416 / Men.Kes / Per / IX / 1990, Regarding the requirements and Supervision of Water Quality of the Republic of Indonesia Minister of Health.

[16] Republic of Indonesia Government Regulation Number: 121 Year 2015 Water Resources Business (SDA)

[17] Putri Arawita Wanggay 2013, Analysis of the Need for Clean Water and Dirty Water in the Sebelas Maret University Surakarta building.

[18] Rini Susanti (2010) Mapping of the Clean Water supply system to improve the water supply system in the town of Lunto rice field, Journal of Regional Planning for the Capital, Volume 21 No 2 Pages 111-128.

[19] Vina Primasari 2010 Utilization of Household Wastewater as a Source of Clean Water by the Simple Biofilter Method, Residents of Surabaya Leucorrhoea.

\footnotetext{
*Corresponding author.

E-mail address: surasa 36@yahoo.com/ Oniver10@ yahoo.com
} 